\title{
GLUCOSE-6-PHOSPHATE DEHYDROGENASE DEFICIENCY AND HAEMOLYTIC DISEASE OF THE NEWBORN IN ISRAEL ${ }^{*}$
}

\author{
BY
ARIEH SZEINBERG, MOSHE OLIVER, RINA SCHMIDT, AVINOAM ADAM and CHAIM SHEBA \\ From the Government Hospital and the Institute of Human Genetics, Tel Hashomer Hospital, Israel
}

(RECEIVED FOR PUBLICATION OCTOBER 5, 1962)

Recent reports from Sardinia, Greece and Malaya indicate that glucose-6-phosphate dehydrogenase (G-6-PD) deficiency may constitute an important aetiological factor in the causation of severe neonatal jaundice and kernikterus (Panizon, 1960a, b; Doxiadis, Fessas and Valaes, 1961; Smith and Vella, 1960; Weatherall, 1960).

Since this enzyme deficiency is very frequent in certain oriental Jewish communities in Israel (Szeinberg, Sheba and Adam, 1958; Sheba, Szeinberg, Ramot, Adam and Ashkenazi, 1962), a high incidence of severe jaundice of newborn not due to iso-immunization could be expected to occur in this country. If this were the case, a considerable disadvantage to carriers of this trait, even under natural conditions (without intake of drugs), would have to be assumed. From the practical point of view such a finding would necessitate the establishment of large-scale facilities for exchange transfusion in the areas inhabited by population groups with a high frequency of G-6-PD deficiency.

A preliminary inquiry among paediatricians in several hospitals did not reveal any awareness of a difference in frequency of severe jaundice and transfusions between Oriental and European (Ashkenazi) Jewish communities. However, in view of the findings in other countries listed above, we decided to investigate this problem more closely. ${ }^{\dagger}$

\section{Material}

The frequency of G-6-PD deficiency in various communities in Israel is presented in Table 1 (Sheba et al., 1962).

\footnotetext{
- The investigations have been supported by grants from World Health Organization (R/00014) and the U.S. National Institutes of Health. Bethesda (A.2740).

+ A preliminary summary of a part of these investigations has been presented at the International Conference of Human Population Genetics. Jerusalem. 1961 (proceedings in the fress).
}

The material for the present investigation consisted of the following groups of subjects.

Group 1. Infants born during a three-and-a-halfyear period (1957-1960) in two villages inhabited by Kurdish and Iranian Jews.

(a) The village of Maoz Zion in the Jerusalem mountains is inhabited by Jews who immigrated to this country from the mountainous region of North-Western Kurdistan (villages of origin: Amadia, Sandor, Dohuk, Al-Kosh and Zakcho). The gene frequency for G-6-PD deficiency in this village is $\mathbf{0 . 7 0}$ (Szeinberg and Adam, 1963). There are about 2,500 inhabitants in this village. All the infants born during the investigation period were delivered in well-established hospitals in Jerusalem.

(b) The village of Noga (near the ancient Gat of the Philistines) has about $\mathbf{5 0 0}$ inhabitants, half of them from Southern regions of Iraqi Kurdistan (Mosul, Kirkuk, Arbel, Sulemaniya) and the other half Persian Jews from Western Iran (Kirmanshah, Senandeg). The gene frequency of G-6-PD deficiency among the Kurdish Jews in this village is $0 \cdot 35$, and among the Iranian group $0 \cdot 15$.

TABLE 1

FREQUENCY OF G-6-PD DEFICIENCY AMONG MALES OF VARIOUS COMMUNITIES IN ISRAEL

(Random Selection)

\begin{tabular}{|c|c|c|c|}
\hline Origin of Subjects & & Sample Size & $\%$ Deficient \\
\hline Ashkenazi Jews & $\ldots$ & 819 & 0.4 \\
\hline $\begin{array}{l}\text { Non-Ashkenazi Jews: } \\
\text { Kurdistan } \\
\text { Iraq } \\
\text { Iran }\end{array}$ & $\begin{array}{l}\cdots \\
\cdots \\
\cdots \\
\cdots \\
\cdots \\
\cdots \\
\cdots \\
\cdots\end{array}$ & $\begin{array}{r}196 \\
902 \\
557 \\
58 \\
102 \\
415 \\
80 \\
256 \\
152 \\
837\end{array}$ & $\begin{array}{r}58 \cdot 2 \\
24 \cdot 8 \\
15 \cdot 1 \\
10 \cdot 3 \\
2.0 \\
5 \cdot 3 \\
6 \cdot 3 \\
1.9 \\
0.7 \\
0.9\end{array}$ \\
\hline Arabs & .. & 264 & $4 \cdot 4$ \\
\hline
\end{tabular}


All the infants born during the investigation period were delivered at the Kaplan Hospital in Rehovoth.

In both villages there are well-organized Mother and Child Welfare Stations recording the pre- and postnatal history of all the infants born. All the records in these stations and in the hospitals where delivery took place were examined by us for the occurrence of jaundice, kernikterus or exchange transfusions.

The blood groups and drugs administered to mothers or infants were recorded as well.

Group 2. The investigation of the relative frequencies of exchange transfusions in newborn babies in various Jewish communities was based on the material of the Kaplan Hospital, where during the period of four and a half years (1957/61) about 12,000 deliveries took place.

In all cases of exchange transfusions the $\mathrm{Rh}$ and $\mathrm{ABO}$ blood group of mother and child were determined at the time of birth.

The origins of the parents of the transfused cases was ascertained during a personal interview. The origins of parents of all the infants born during the investigated period at the hospital were obtained from the registration cards of the hospital archives.

Group 3. In four Government Hospitals situated in different areas of Israel (Tel-Aviv-Lydda area, Haifa and Tiberias) 32,000 deliveries took place during the 1957-61 period. All case reports with the diagnosis of haemolytic disease of the newborn were examined by us for the relevant details. The diagnosis in all cases was made by the attending paediatricians in the respective hospitals. In view of the inherent difficulties in the differential diagnosis between haemolytic disease and jaundice from other causes in the neonatal period, some reservations should probably be made in respect to the accuracy of diagnosis of this case material.

\section{Methods}

G-6-PD activity in red cells was assayed by a slightly modified spectrophotometric method of Kornberg and Horrecker (1955) as used in our laboratory (Ramot, Szeinberg, Adam, Sheba and Gafni, 1959).

Values above 10 units/g. Hb were considered normal, 3-10 units/g. Hb intermediate and below 3 units/g. Hb fully enzyme deficient. When sufficient blood was available a parallel assay of glutathione stability was also performed (Beutler, 1957).

Calculations of the expected number of enzymedeficient subjects in the investigated groups were based upon the X-chromosome linkage of G-6-PD deficiency, the frequency of male enzyme-deficient subjects being equal to the frequency of the pathological gene $(q)$, that of homozygous females $=\mathrm{q}^{2}$ and heterozygous females $=2 \mathrm{pq}$.

\section{Results}

A Survey in Villages Inhabited by Kurdish and Iranian Jews

Group la. In the village of Maoz Zion 203 infants were born during the investigation period.
It was calculated that among them the expected number of fully enzyme-deficient infants (hemizygous males and homozygous females) was 122 and the number of heterozygous females 42 .

In three cases a deep jaundice requiring exchange transfusions developed. In one of them $R h$ isoimmunization was proved by direct and indirect Coombs test. In the other two cases (two sisters) the infants belonged to $A$ and the mother to $O$ blood groups. In both cases iso-immunization was proved by a direct Coombs test. In an additional 26 cases, jaundice was observed. However, only in seven of those did the clinical condition necessitate bilirubin estimation, and the highest level was $11 \mathrm{mg} . / 100 \mathrm{ml}$. None of these jaundiced infants required prolonged periods in hospital nor special treatment and none was diagnosed as suffering from haemolytic disease of the newborn. These cases belonged most probably to the group designated 'physiological jaundice'.

Group $1 b$. In the village of Noga 61 infants in the Kurdish families and 59 in the Iranian ones were born during the period of investigation. The expected number of fully enzyme-deficient infants was 16 and the number of heterozygous females 18 . None of the newborn in this group developed kernikterus or jaundice requiring an exchange transfusion.

On examination of the hospital records we have found that in $44 \%$ of the infants jaundice was observed. This high figure suggested the possibility of a particularly high incidence of jaundice in the investigated group. However, in a control group of 200 consecutive newborns from different communities in the same hospital, jaundice was recorded in $53 \%$. Thus, most probably the hospital paediatricians were 'jaundice conscious' and recorded every slight case of physiological jaundice. According to Smith (1959), 'probably at least $50 \%$ and possibly as many as $75 \%$ of normal babies may show some degree of jaundice from causes and adjustments considered to be "physiological" shortly after birth'.

In conclusion it may be stated that in the two villages with high frequencies of enzyme deficiency no case of severe jaundice or kernikterus unexplainable by iso-immunization occurred during a threeand-a-half year investigation period.

Frequency of Exchange Transfusions in Various
Population Groups Differing in Frequency of Enzyme
Deficiency
Group 2. At the Kaplan Hospital 12,389 infants were born during the 1957-61 period and 44 
exchange transfusions were performed (13 cases with $\mathrm{Rh}$ and 26 with $\mathrm{ABO}$ incompatibility, five cases without blood group incompatibility). The ethnic distribution of cases which were not due to $R h$ incompatibility fitted rather closely that of all the cases born during the period of investigation (Table 2). There was no indication that communities with a very high frequency of enzyme deficiency (Kurdish, Iraqi and Iranian) produced more cases requiring exchange transfusions than those in which the abnormality was very rare (e.g. Ashkenazi Jews). G-6-PD activity was determined in all the transfused cases in which the jaundice was not due to $\mathrm{Rh}$ incompatibility. The ABO incompatibility group was examined, because the existence of the incompatibility could not be taken prima facie as a proof for an immunological basis of the jaundice. The titre of anti A or anti B antibodies in the blood of the mothers soon after delivery varied between $1 / 2$ and 1/256. Tests for detection of a state of iso-immunization were usually not periormed.

Among the 31 cases examined only three enzymedeficient cases were found, namely two Iraqi infants (one male and one female) in the group with ABO incompatibility and one Kurdish male infant without history of blood group incompatibility. This number of enzyme-deficient cases did not differ significantly from that expected in a random sample of a population of similar ethnic composition. Thus no indication was obtained in this investigated group pointing to an aetiological connexion between G-6-PD deficiency and haemolytic jaundice of the newborn in our population.

\section{Occurrence of Neonatal Jaundice in Different Population Groups}

Group 3. Among 32,000 infants born in four government hospitals, 271 developed jaundice diagnosed as haemolytic disease of the newborn not due to $R h$ iso-immunization. In 215 of these ABO incompatibility was present, and in 56 it was absent. The majority of cases were mild and only 47 required an exchange transfusion (42 with $A B O$ incompatibility and five without incompatibility). During the same period 80 cases of haemolytic jaundice due to $R h$ incompatibility were observed.

Ten infants died of kernikterus. Two of those were premature; in three $R h$ and in three $A B O$ incompatibility existed. In two cases only was no blood group incompatibility found, but in one of those prolapse of cord, bronchopneumonia and sepsis were complicating factors (Table 3). In none of these 10 infants was G-6-PD examination performed. In three cases (Cases 4, 8, 10) the mothers
TABLE 2

EXCHANGE TRANSFUSIONS PERFORMED DURING 1957-61 IN CASES OF SEVERE NEONATAL JAUNDICE NOT DUE TO RH INCOMPATIBILITY

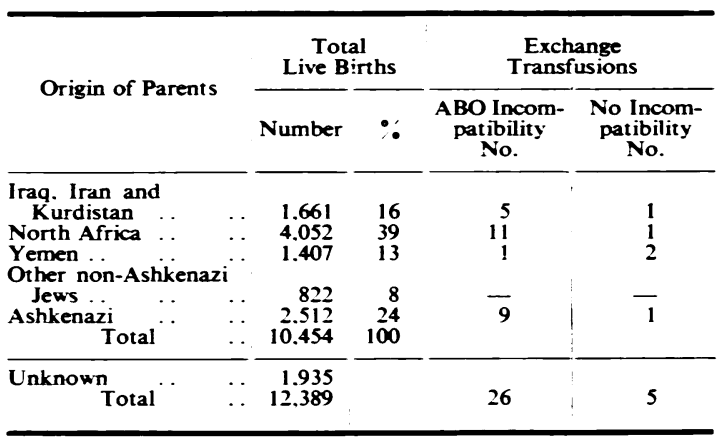

were examined and had a normal enzyme activity. This material did not suggest any increased frequency of kernikterus in communities with a high incidence of G-6-PD deficiency.

The ethnic distribution of the 271 cases of haemolytic jaundice not due to $R h$ incompatibility is presented in Table 4. As there was no possibility of obtaining accurate data on the community distribution of all the birth cases in the investigated hospitals during the same period, the comparison of the different communities was made through an index representing the ratio between cases without incompatibility to those with $\mathrm{ABO}$ incompatibility. We presumed that if the enzyme deficiency was a causative agent in the aetiology of haemolytic disease of the newborn, this ratio would be higher in communities with a high frequency of G-6-PD deficiency. However, as may be seen from Table 4, the result was negative. The comparative index was not significantly different in the various Jewish communities.

TABLE 3

CASES OF KERNIKTERUS OBSERVED AMONG 32,000 INFANTS BORN IN FOUR GOVERNMENT HOSPITALS

\begin{tabular}{|c|c|c|c|}
\hline $\begin{array}{l}\text { Case } \\
\text { No. }\end{array}$ & $\begin{array}{l}\text { Origin of } \\
\text { Parents }\end{array}$ & Sex & Description \\
\hline $\begin{array}{l}\mathbf{1} \\
\mathbf{2} \\
\mathbf{3}\end{array}$ & $\begin{array}{l}\text { Ashkenazi } \\
\text { North Africa } \\
\text { Not known }\end{array}$ & $\begin{array}{l}\mathbf{M} \\
\mathbf{M}\end{array}$ & $\begin{array}{l}\text { Rh incompatibility } \\
\text { Rh incompatibility, sepsis } \\
\text { Rh incompatibility }\end{array}$ \\
\hline $\begin{array}{l}4 \\
5 \\
6\end{array}$ & $\begin{array}{l}\text { Ashkenazi } \\
\text { Arab } \\
\text { Iraq }\end{array}$ & $\begin{array}{l}\mathbf{M} \\
\mathbf{M} \\
\mathbf{M}\end{array}$ & $\begin{array}{l}\text { AO incompatibility } \\
\text { AO incomsatibility } \\
\text { AO incompatibility }\end{array}$ \\
\hline $\begin{array}{l}7 \\
8\end{array}$ & $\begin{array}{l}\text { North Africa } \\
\text { Iraq }\end{array}$ & $\mathbf{M}$ & $\begin{array}{l}\text { Prematurity (birth weight } 1,470 \mathrm{~g} \text { ) } \\
\text { Prematurity (birth weight } 1,200 \mathrm{~g} \text { ) }\end{array}$ \\
\hline $\begin{array}{r}9 \\
10\end{array}$ & $\begin{array}{l}\text { Yemen } \\
\text { Syria }\end{array}$ & $\begin{array}{l}\mathbf{F} \\
\mathbf{M}\end{array}$ & $\begin{array}{l}\text { No incompatibility; prolapse of cord, } \\
\text { bronchopneumonia, sepsis } \\
\text { No incompatibility }\end{array}$ \\
\hline
\end{tabular}


TABLE 4

CASES OF NEONATAL HAEMOLYTIC JAUNDICE NOT DUE TO RH INCOMPATIBILITY OBSER VED AMONG 32.000 INFANTS BORN IN FOUR GOVERNMENT HOSPITALS

\begin{tabular}{|c|c|c|c|}
\hline $\begin{array}{l}\text { Origin } \\
\text { of } \\
\text { Parents }\end{array}$ & $\begin{array}{c}\text { ABO } \\
\text { Incom- } \\
\text { patibility }\end{array}$ & $\begin{array}{c}\text { No } \\
\text { Incom- } \\
\text { patibility }\end{array}$ & $\begin{array}{c}\text { Rario- } \\
\text { No Incompatibility: } \\
\text { ABO Incompatibility }\end{array}$ \\
\hline $\begin{array}{lll}\text { Ashbenazi } & \ldots & \ldots \\
\text { Iraq } \ldots & \ldots & \ldots \\
\text { North Africa } & \ldots \\
\text { Other Oriental Jews. } \\
\text { Arabs } & \ldots & \ldots\end{array}$ & $\begin{array}{l}75 \\
28 \\
44 \\
44 \\
24\end{array}$ & $\begin{array}{r}23 \\
9 \\
11 \\
11 \\
2\end{array}$ & $\begin{array}{l}0 \cdot 30 \\
0 \cdot 32 \\
0 \cdot 25 \\
0 \cdot 25 \\
0 \cdot 08\end{array}$ \\
\hline Total . . & 215 & 56 & \\
\hline
\end{tabular}

TABLE 5

G-6-PD DEFICIENCY AMONG CASES OF NEONATAL HAEMOLYTIC JAUNDICE NOT DUE TO RH INCOMPATIBILITY

\begin{tabular}{|c|c|c|c|c|}
\hline \multirow{2}{*}{$\begin{array}{l}\text { Origins } \\
\text { of } \\
\text { Parents }\end{array}$} & \multicolumn{2}{|c|}{$\begin{array}{c}\text { With ABO } \\
\text { Incompatibility }\end{array}$} & \multicolumn{2}{|c|}{$\begin{array}{l}\text { Without ABO } \\
\text { Incompatibility }\end{array}$} \\
\hline & $\begin{array}{l}\text { No. } \\
\text { Investi- } \\
\text { gated }\end{array}$ & $\begin{array}{c}\text { No. } \\
\text { G-6-PD } \\
\text { Deficient }\end{array}$ & $\begin{array}{c}\text { No. } \\
\text { Invest:- } \\
\text { gated }\end{array}$ & $\begin{array}{c}\text { No. } \\
\text { G-6-PD } \\
\text { Deficient }\end{array}$ \\
\hline $\begin{array}{ll}\text { Ashkenazi } & \ldots \\
\text { Iraq } & \ldots \\
\text { Other Orienta! Jews } \\
\text { Arabs }\end{array}$ & $\begin{array}{r}24 \\
12 \\
37 \\
7\end{array}$ & $\begin{array}{l}0 \\
4 \\
1 \\
0\end{array}$ & $\begin{array}{r}16 \\
8 \\
20 \\
2\end{array}$ & $\begin{array}{l}1 \\
7 \\
0 \\
0\end{array}$ \\
\hline
\end{tabular}

Only among the Arab infants the index was significantly lower. We do not have a sure explanation for this finding, but it is possible that it could be connected with the fact that Arab women generally preferred to deliver at home, but those with previous histories of neonatal jaundice due to blood group incompatibility were strongly advised in the regional health centres to use the hospital services.

All the available cases with no blood group incompatibility and a part of those of the $\mathrm{ABO}$ incompatibility group were examined for the presence of enzyme deficiency (Table 5). In the $\mathrm{ABO}$ group the findings were compatible with those expected from the frequencies of G-6-PD deficiency in the respective populations. However, significantly different findings were obtained among the infants without blood group incompatibility. Among eight infants born to Iraqi Jewish parents, seven were enzyme deficient (the expected number was about two). Although the sample was very small, the difference between the expected and the observed number of enzyme-deficient cases was statistically significant $\left(\chi^{2}=13.5, \mathrm{p}<0.001\right)$. Beside the above cases of Iraqi origin, one Ashkenazi infant was also found to be enzyme deficient.

Among the eight enzyme-deficient infants without history of blood group incompatibility, seven were males and one female. Only one of them required an exchange transfusion (on the sixth day of life). In the others the jaundice was not very deep. The highest blood bilirubin level in one infant was $17.5 \mathrm{mg}$. $/ 100 \mathrm{ml}$., in the others below $15 \mathrm{mg} . / 100 \mathrm{ml}$. In two cases the jaundice was visible on the first day of life (one of them with a condition of asphyxia livida), in all the others it was first observed on the third or fourth day.

The jaundice was prolonged in all these eight infants (in one case up to one month), but it subsided without complications. In none of the infants did kernikterus or neurological sequelae develop. Only one received vitamin $\mathrm{K}(1 \mathrm{mg}$.). None of the others or their mothers received any drugs known to cause haemolysis in sensitive subjects. No contact with moth balls or other naphthalene preparations was recorded.

It is interesting to note that on the date of birth of the infant who later required an exchange transfusion, its sibling (aged 1 year) was admitted to the paediatric ward with a severe haemolytic anaemia necessitating a blood transfusion.

In six of the eight families, a history of neonatal jaundice in preceding siblings was recorded. In the seventh family no such occurrence was observed in six siblings and in the eighth family (of Ashkenazi origin) the jaundiced infant was the only child.

\section{Discussion}

The data quoted in the literature suggest that in Greece, in Sardinia and in Malaya G-6-PD deficiency constitutes a major aetiological factor in the causation of haemolytic jaundice of the newborn. Although in most reports no data are given on the relative frequency of such occurrences among the enzymedeficient infants, they suggest that G-6-PD deficiency may account for the majority of cases not due to iso-immunization.

Weatherall (1960) recorded four male cases of severe neonatal haemolytic jaundice resulting in kernikterus in three Malayan families seen at the British Military Hospital in Singapore. During the same period 600 Malay births were recorded in that hospital.*

G-6-PD deficiency is rare among the Malayans. According to Vella (1961) its frequency is $0.65 \%$. Thus, it can be calculated that the expected number of enzyme-deficient boys among the 600 birth cases was about two. The finding of several cases in the material of this magnitude would suggest a very high frequency of haemolytic occurrences in enzymedeficient newborns.

\footnotetext{
- However, it is not clear from the report whether three of the four cases were born at the hospital or in some other place, and were later admitted to the hospital because of doep jaundice.
} 
Smith and Vella (1960) reported, from the Singapore area, that in the majority of cases of kernikterus no blood group incompatibility existed. Among 14 such cases of Chinese or Malay origin they found 13 enzyme deficient.

Panizon $(1960 \mathrm{a}, \mathrm{b})$ reported on 19 cases of kernikterus in enzyme-deficient infants in northern Sardinia. According to this investigator enzyme deficiency is a major aetiological factor in the causation of kernikterus in that region. The frequency of G-6-PD deficiency in the investigated population was $6-7 \%$, and yet the number of enzyme-deficient cases of kernikterus without blood group incompatibility surpassed the number due to iso-immunization.

Doxiadis et al. (1961) reported from Greece that in about one-third of cases of severe neonatal jaundice requiring exchange transfusion, no blood group incompatibility existed. In the majority of those cases G-6-PD deficiency was found, although the frequency of this defect in the general population was very low (in 100 consecutive control birth cases only one was found to be enzyme deficient). The investigators suggested also that heterozygous females with normal G-6-PD activity (as determined by the screening test used by them) could develop this type of jaundice.

In a later report, Fessas (1963) stated that in the above population the frequency of G-6-PD deficiency among males was about $2.5 \%$ and the chances of one of the enzyme-deficient children developing a severe haemolytic jaundice on the basis of the defect was about $5 \%$.

In contrast to the above reports the present investigation does not suggest that G-6-PD deficiency constitutes a major aetiological factor in the causation of severe neonatal jaundice in Israel.

In the two villages inhabited by Kurdish and Iranian Jews with a very high frequency of enzyme deficiency presumably about 140 fully enzymedeficient infants were born during a three-and-a-halfyear period (hemizygous males and homozygous females). On the basis of the $5 \%$ risk suggested by Fessas, some seven cases of severe haemolytic jaundice among them could be expected. However, no such case was recorded.

Among the 44 cases of exchange transfusions in infants of different Jewish communities only in five $(11 \%)$ was there no blood incompatibility. Of those only one infant of Kurdish origin was enzyme deficient.

No significant differences in the frequency of exchange transfusions between communities with very high and those with very low incidence of enzyme deficiency were observed.
Among 271 cases of infants in whom haemolytic jaundice not due to $R h$ incompatibility was diagnosed, the cases with no blood incompatibility constituted only about $25 \%$. No significant difference in this respect was found between the various Jewish communities investigated.

There was only one finding suggesting that some cases of neonatal jaundice due to enzyme deficiency did occur in this country. A significant difference between the expected and observed number of G-6-PD deficient infants was found in a small sample of jaundiced cases born in Iraqi Jewish families. It should be noted, however, that with one exception the cases were mild and did not require exchange transfusions.

The cause of the difference between the findings in Israel and the other countries is not known. In a few cases in Sardinia and about one-third of cases in Greece (Fessas, 1963) exposure to drugs (gantrisin, vitamin K), or naphthalene could possibly constitute the precipitating factor in the development of haemolysis. In Sardinia fava beans are extensively grown and consumed. A possibility therefore exists that a haemolytic factor is transmitted with the milk of the nursing mother to the infant. It is also possible that some other food product, common in the investigated countries, contains or metabolizes to an agent potentially haemolytic to the enzyme-deficient newborn. Smith and Vella (1960) suggested that the factor precipitating haemolysis in their cases might be related to traditional Chinese methods of care for mother and child during the puerperium. Some viral and bacterial infections might lead to a haemolytic crisis in enzyme-deficient subjects (Szeinberg et al., 1958). Panizon (1960b) observed in a significant proportion of his cases the existence of maternal factors that could cause foetal anoxia or pathological delivery. Differences in regard to any of the above-listed precipitating factors could possibly play a significant role in the determination of the frequency of severe neonatal jaundice due to enzyme deficiency in Israel and in other countries involved.

Another possible explanation may be derived from the observations of Panizon (1960a) and Fessas (1963) of a high incidence of the syndrome in a few families involved. These investigators suggested that another genetic factor or some particular environmental effect existing in the affected families might be involved in these cases. It should be noted also that in our enzyme-deficient cases the familial aggregation of neonatal jaundice was evident. It is possible that the additional factors (hypothetical at present) suggested by 
Panizon and Fessas are more frequent in the other populations involved than in ours.

On the basis of the reports from Greece, Sardinia and Singapore, Motulsky (1961) suggested that mortality from haemolytic diseases of the newborn caused by enzyme deficiency was probably the most important deleterious effect of the gene, counteracting its protective value against deaths from falciparum malaria. Our investigation did not demonstrate a frequent occurrence of severe haemolytic reactions in enzyme-deficient newborns. Admittedly, it should be taken into account, that our investigation was conducted in Israel, where most of the people were newcomers, and not in the countries where they lived for centuries. We cannot exclude the possibility that in those countries conditions precipitating haemolysis of newborn did exist and that they had a significant influence on the establishment of a balanced polymorphism of glucose-6-phosphate dehydrogenase. However, the fact that the frequency of enzyme deficiency among Jews who were born in Kurdistan and came later to Israel reached $70 \%$ militates against the conclusion that the gene had a significant detrimental effect in their country of origin.

\section{Summary}

The importance of glucose-6-phosphate dehydrogenase deficiency in the causation of severe neonatal jaundice in Israel was investigated.

Communities with very high frequencies of enzyme deficiency and those in which it was very rare did not differ significantly in the frequency of severe neonatal jaundice not due to iso-immunization.

However, in one investigated sample of Iraqi Jews the number of enzyme-deficient cases among the jaundiced infants was significantly higher than expected from the gene frequency, suggesting that some cases of haemolytic disease of newborn due to enzyme deficiency did occur in this group. With one exception all the cases were mild and did not require exchange transfusions.

The overall results suggest that although a few such cases may occur in this country, glucose-6- phosphate dehydrogenase deficiency cannot be considered an important aetiological factor in the causation of severe haemolytic neonatal jaundice in Israel, in spite of the existence of population groups with a very high frequency of the enzyme deficiency.

The possible causes of differences between the findings in Israel and those reported from Greece, Sardinia and Malaya are discussed.

We wish to thank Dr. N. Jonas, Dr. G. Mundel. Dr. A. Gotlieb, Dr. J. Barhai, Dr. M. Selzer and Dr. A. Friedman, from the paediatric departments of the 'Kaplan' Hospital, Rehovoth, 'Assaf Harofe' Hospital. Zerifin, 'Zahalon' Hospital, Jaffa, 'Rambam' Hospital. Haifa, and 'Poriah' Hospital, Tiberias, and to the social nurses in the Regional Health Centres who enabled us to obtain the material for this investigation.

\section{REFERENCES}

Beutler, E. (1957). The glutathione instability of drug-sensitive red cells. A new method for the in vitro detection of drug sensitivity. J. Lab. clin. Med., 49, 84.

Doxiadis, S. A., Fessas, Ph. and Valaes, T. (1961). Glucose-6phosphate dehydrogenase deficiency. A new aetiological factor phosphate dehydrogenase deficiency. A new

Fessas. Ph. (1963). Discussion on Glucose-6-Phosphate Dehydrogenase Deficiency and Neonatal Jaundice. Proc. Intern. Conf. Human Population Genetics, Jerusalem, 1961. In the press.

Kornberg. A. and Horecker, B. (1955). Glucose-6-phos phate dehydrogenase. In Methods in Enzymology, ed. S. P. Colowick and N. O. Kaplan, Vol. 1. D. 323. Academic Press, New York.

Motulsky, A. G. (1961). Glucose-6-phosphate-dehydrogenase deficiency, haemolytic disease of the newborn, and malaria. Lancet, 1. 1168 .

Panizon, F. (1960a). Erythrocyte enzyme deficiency in unexplained kernicterus. ibid., 2, 1093.

(1960b). L Lictère Grave du Nouveau-né Associè à une Déficience en Glucose-6-Phosphate Déhydrogénase. Biol. Neonat. (Basel), 2, 167.

Ramot. B., Szeinberg, A., Adam, A., Sheba, Ch. and Gafni, D. (1959). A study of subjects with erythrocyte glucose-6-phosphate dehydrogenase deficiency: Investigation of platelet enzymes. dehydrogenase deficiency:
J. clin. Invest., 38, 1659 .

Sheba, Ch., Szeinberg. A., Ramot, B., Adam, A. and Ashkenazi, I. (1962). Epidemiologic surveys of deleterious genes in different population groups in Israel. Amer. J. publ. Hlth, 52, 1101.

Smith, C. A. (1959). The Physiology of the Newborn Infant, 3rd ed., p. 184. Thomas, Soringfield, Illinois.

Smith, G. D. and Vella, F. (1960). Erythrocyte enzyme deficiency in unexplained kernicterus. Lancet, 1, 1133.

Szeinberg, A. and Adam, A. (1963). Glucose-6-Phosphate Dehydrogenase Deficiency Among Jews. Genetic and Anthropologic genase Deficiency Among Jews. Genetic and Anthropologic
Considerations. Proc. Intern. Conf. Human Population Considerations. Proc. Intern. Conf.

Genetics, Jerusalem, 1961. In the press.
Sheba, Ch. and Adam, A. (1958). Selective occurrence of glutathione instability in red blood corpuscles of the various Jewish tribes. Blood, 13, 1043.

Vella, F. (1961). The incidence of erythrocyte glucose-6-phosohate dehydrogenase deficiency in Singapore. Experientia (Basel), 17, 181 .

Weatherall, D. J. (1960). Enzyme deficiency in haemolytic disease of the newborn. Lancet, 2,835 . 